\title{
EMPIRICAL ANALYSIS OF E-MODULE BASED ON SCIENCE LITERATION AS A SOURCE IN LEARNING ELECTROMAGNETIC RADIATION MATERIAL
}

\author{
Zurryati Syahputri $^{* 1)}$, M. Rahmad $^{2)}$, Mitri Irianti ${ }^{3)}$, Dina Veranita ${ }^{4)}$ \\ ${ }^{1,2,3)}$ Physics Education, University of Riau, \\ 4) Riau Province Integrated Agricultural Vocational School \\ e-mail: zurryatis@gmail.com \\ m.rahmad@lecturer.unri.ac.id \\ mitri.irianti@lecturer.unri.ac.id
}

\begin{abstract}
E-module based on scientific literacy of electromagnetic radiation material has been validated by experts, but this e-module has not been applied to students in learning in schools. This research aimed to determine the empirical validity of e-modules based on scientific literacy as a source of learning material for electromagnetic radiation. The research method used is the 4D method, namely: defining, design, development and dissemination. This research focuses on the development stage, that limited testing. The research data analysis technique used is descriptive analysis. Respondents from this research were class $X$ students and teachers of Riau Province Integrated Agriculture Vocational School, totaling 23 students and 2 teachers. The research data were obtained using an empirical validity questionnaire instrument. The results of the analysis of the empirical validity test data of e-module based on scientific literacy which include design aspects, content aspects, pedagogical aspects, and technical aspects obtained an average score of 4.34 with a high validity category. So, it can be concluded that e-module based on scientific literacy as a source of learning material for electromagnetic radiation, is declared valid and can be used in learning for students in senior high schools or agriculture vocational high school.
\end{abstract}

Keywords: e-module, empirical validity, science literacy, electromagnetic radiation. 


\title{
ANALISIS EMPIRIS E-MODUL BERBASIS LITERASI SAINS SEBAGAI SUMBER BELAJAR MATERI RADIASI ELEKTROMAGNETIK
}

\author{
Zurryati Syahputri $^{* 1)}$, M. Rahmad ${ }^{2)}$, Mitri Irianti ${ }^{3)}$, Dina Veranita ${ }^{4}$ \\ ${ }^{1,2,3)}$ Pendidikan Fisika, Universitas Riau \\ 4) SMK Pertanian Terpadu Propinsi Riau
}

\begin{abstract}
Abstrak
E-modul berbasis literasi sains materi radiasi elektromagnetik ini telah divalidasi oleh para ahli, namun emodul ini belum diterapkan kepada peserta didik dalam pembelajaran di sekolah. Penelitian ini bertujuan untuk mengetahui validitas empiris dari e-modul berbasis literasi sains sebagai sumber belajar materi radiasi elektromagnetik. Metode Penelitian yang digunakan adalah metode 4D yaitu: pendefinisian, desain, pengembangan dan penyebaran. Penelitian ini berfokus pada tahap pengembangan yaitu uji coba terbatas. Teknik analisis data penelitian yang digunakan adalah analisis deskriptif. Responden dari penelitian ini adalah peserta didik kelas X dan guru SMK Negeri Pertanian Terpadu Provinsi Riau yang berjumlah 23 orang peserta didik dan 2 orang guru. Data penelitian diperoleh menggunakan instrumen kuesioner validitas empiris. Hasil analisis data uji validitas empiris e-modul berbasis literasi sains yang meliputi aspek desain, aspek isi, aspek pedagogi, dan aspek teknis diperoleh skor rata-rata 4,34 dengan kategori validitas tinggi. Sehingga, dapat disimpulkan bahwa e-modul berbasis literasi sains sebagai sumber belajar materi radiasi elektromagnetik, dinyatakan valid dan dapat digunakan dalam pembelajaran bagi peserta didik di sekolah menengah atas atau sekolah menengah kejuruan pertanian.
\end{abstract}

Kata kunci: e-modul, validitas empiris, literasi sains, radiasi elektromagnetik.

\section{Pendahuluan}

Kemajuan teknologi yang berkembang dibuktikan dengan banyaknya inovasi-inovasi yang dibuat oleh manusia mulai dari yang sederhana hingga yang rumit. Sistem komunikasi dan teknologi menjadi media penyajian informasi ilmiah yang tak terbatas mengenai isu-isu penting terkait ilmu pengetahuan dan teknologi. Setiap orang menggunakan teknologi untuk mencari ataupun berbagi dalam pemenuhan informasi ilmiah tentang pemahaman alam semesta, isuisu ilmiah, dan perkembangan sains saat ini, baik untuk keperluan pengetahuan personal maupun inovasi ilmu pengetahuan bidang sains. Demi menunjang kelangsungan hidup, kecerdasan manusia selalu ditingkatkan, satu diantaranya melalui pendidikan di sekolah. Pemerintah perlu melakukan segala upaya untuk mencerdaskan kehidupan bangsa melalui pendidikan, yaitu dengan pemberian pembelajaran sains sebagai bagian perkembangan kurikulum di sekolah. Sains atau IPA adalah pengetahuan yang didapatkan secara sistematis tentang struktur dan perilaku fenomena alam, sedangkan teknologi merupakan aplikasi dari sains. Bagi setiap individu dalam masyarakat melek sains dan teknologi perlu diterapkan, karena dengan penguasaan ilmu pengetahuan sains dan teknologi, seseotrang dapat berpartisipasi secara penuh dalam masyarakat (Sri Rahayu, 2014).

Mata pelajaran fisika yang termasuk dalam rumpun pelajaran Sains, perlu diberikan kepada semua peserta didik mulai dari sekolah dasar untuk membekali peserta didik dengan kemampuan berpikir logis, analitis, sistematis, kritis, dan kreatif, serta kemampuan bekerja sama (Nurdini, 2013). Sebagai landasan pengembangan teknologi, sudah seharusnya fisika menjadi pelajaran yang dikuasai dan difahami oleh peserta didik (Ferry Perdiansyah, 2014).

Kenyataannya, pada umumnya fisika masih merupakan pelajaran yang ditakuti, sulit, dan dianggap tidak menarik bagi peserta didik di Indonesia. Hal tersebut dikarenakan dalam mempelajari fisika, peserta didik harus mampu memahami konsep yang terkandung didalamnya, menuliskannya dalam simbolsimbol fisis, dan harus memahami per- 
masalahan, lalu menyelesaikannya secara matematis. Oleh karena itu, salah satu upaya yang dilakukan untuk mengatasi kesulitan belajar peserta didik dan meningkatkan prestasi peserta didik pada pelajaran fisika adalah dengan mengembangkan sumber belajar yang berbasis komputer seperti penggunaan E-modul (Trianto, 2007). E-modul merupakan bahan pembelajaran atau modul berisi materi pelajaran yang disajikan dalam bentuk media elektronik yang berbasis komputer (Dwi Rahdiyanta, 2010). Hasil kajian Nana Nurjannati et al. (2017) telah mendapatkan hasil pengembangan E-modul berbasis literasi sains pada materi Radiasi Elektromagnetik yang sudak dinyatakan valid dengan kategori sangat layak, namun belum dilakukan uji empiris di lapangan, sehingga perlu dilakukan kajian lanjutan untuk mengetahui penilaian pengguna.

Menurut Munafiah (2018) analisis empiris menjadi penting karena dengan analisis empiris dapat menentukan validitas dari sebuah multimedia interaktif materi hukum Newton tentang gerak. Hal ini menunjukkan bahwa media tersebut dinyatakan valid dan dapat di teliti dalam aspek efektivitas penggunaan. Hal ini didukung oleh hasil penelitian Dimistrios (2008) yang menyatakan bahwa analisis empiris dapat meningkatkan level kegunaan dengan waktu yang lebih fleksibel terhadap pemakaian $e$ modul. Selain itu, Wai Kit Wong (2016) juga mengemukakan bahwa analisis empiris, dapat berfungsi sebagai informasi mengenai fleksibilitas dan efektivitas sebuah sumber belajar yang menggunakan sistem elektronik. Tujuan dalam kajian ini adalah untuk mengetahui hasil uji empiris dari e-modul berbasis literasi sains sebagai sumber belajar materi Radiasi Elektromagnetik yang sudah valid untuk diterapkan.

\section{Bahan dan Metode}

Penelitian analisis empiris e-modul berbasis literasi sains sebagai sumber belajar pada materi radiasi elektromagnetik ini dilakukan di kelas X SMK Negeri Pertanian Terpadu Provinsi Riau. Penelitian ini menggunakan metode 4D, yang berfokus pada tahap pengembangan yaitu uji coba terbatas.
Rancangan penelitian digambarkan pada Gambar 1.



Gambar 1. Rancangan Penelitian 4-D

Keterangan :

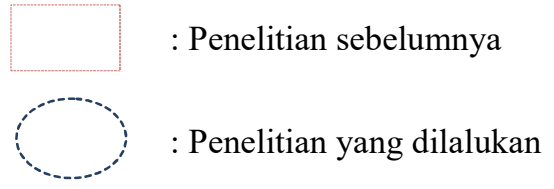

Responden dalam kajian ini adalah peserta didik kelas X SMK Negeri Terpadu Provinsi Riau yang terdiri dari 23 orang dan dan 2 orang guru Fisika. Teknik pengumpulan data pada penelitian ini dilakukan dengan pengisian kuesioner oleh responden yaitu peserta didik dalam skala terbatas. Kuesioner diberikan kepada peserta didik setelah e-modul disajikan kepada peserta didik dan dikumpul kan setelah peserta didik mengisi kuesioner. Data yang diperoleh merupakan data primer yang diperoleh langsung oleh pengkaji. Setelah kuesioner dikumpulkan dilakukan sesi wawancara singkat kepada peserta didik, untuk mengetahui keefektifan dari $e$-modul. 
Tabel 1. Rubrik skor penilaian

\begin{tabular}{clc}
\hline No & \multicolumn{1}{c}{ Kategori } & Skor \\
\hline 1 & Sangat setuju & 5 \\
2 & Setuju & 4 \\
3 & Kurang Setuju & 3 \\
4 & Tidak setuju & 2 \\
5 & Sangat Tidak Setuju & 1 \\
\hline
\end{tabular}

Sumber: (Sugiyono, 2015).

Teknik analisis data menggunakan analisis deskriptif melalui uji validitas berdasarkan nilai rata-rata. Analisis deskriptif bertujuan menganalisis data dengan cara mendeskripsikan atau menggambarkan data yang telah terkumpul untuk memberikan gambaran tentang validitas empiris e-modul berbasis literasi sains sebagai sumber belajar materi radiasi elektromagnetik. Validitas empiris dapat dilihat melalui skor yang diperoleh dari pengisian kuesioner. Adapun rubrik skor penilaian dari kuesioner dapat dilihat pada Tabel 1. Selanjutnya nilai validitas e-modul ditentukan menggunakan skala likert menurut Tabel 2.

Tabel 2. Skala likert penentuan kategori validitas

\begin{tabular}{|c|c|c|}
\hline No & $\begin{array}{c}\text { Interval Rata-rata } \\
\text { Skor }\end{array}$ & Kategori Valid \\
\hline 1 & $4<$ rata-rata $\leq 5$ & Validitas Tinggi \\
\hline 2 & $3<$ rata-rata $\leq 4$ & Valid \\
\hline 3 & $2<$ rata-rata $\leq 3$ & $\begin{array}{l}\text { Validitas } \\
\text { Sedang }\end{array}$ \\
\hline 4 & $1<$ rata-rata $\leq 2$ & Tidak Valid \\
\hline 5 & $0<$ rata-rata $\leq 1$ & $\begin{array}{l}\text { Sangat Tidak } \\
\text { Valid }\end{array}$ \\
\hline
\end{tabular}

Sumber : Muhammad Nasir (2017).

\section{Hasil dan Pembahasan}

Penelitian ini dilakukan dengan menggunakan uji coba terbatas. Produk berupa e-modul berbasis literasi sains sebagai sumber belajar pada materi radiasi elektromagnetik yang telah dikembangkan dan divalidasi oleh peneliti sebelumnya (Nana Nurjannati et. al, 2019). E-modul telah divalidasi oleh dosen FKIP UNRI dan guru SMA sederajat. Data yang diperoleh dari kuesioner yang terdiri dari 29 item dan 4 aspek berisi pernyataan mengenai penilaian e-modul berbasis literasi sains sebagai sumber belajar pada materi radiasi elektromagnetik meliputi aspek desain, aspek pedagogi, aspek isi dan juga aspek teknis yang kemudian para responden memberikan skor pada pernyataan dari kuesioner tersebut.

Jumlah responden yang mengisi kuesioner pada kajian uji validitas empiris adalah 23 orang peserta didik dan 2 guru SMK Negeri Pertanian Terpadu Provinsi Riau. Data tersebut telah dianalisis dan diuji validitasnya menggunakan bantuan program microsoft excel dan menggunakan rumus rata-rata untuk menguji validitas setiap aspek.

Hasil uji validitas e-modul berbasis literasi sains pada materi Radiasi Elektromagnetik dengan menggunakan lembar kuesioner yang diberikan kepada peserta didik ditunjukkan pada Tabel 3. Hasil analisis data diperoleh uji validitas empiris pada aspek desain memiliki rata-rata 4,44 , aspek pedagogi 4,17, aspek isi 4,42, dan aspek teknis 4,34 dimana setiap aspek berkategori validitas tinggi. Skor terendah pada aspek pedagogi, namun tetap dalam kategori validitas tinggi dan sesuai dengan hasil validitas akhir dari e-modul berbasis literasi sains yang skornya 4,34 dengan kategori validitas tinggi.

Hasil uji validitas e-modul berbasis literasi sains pada materi Radiasi Elektromagnetik melalui lembar kuesioner yang diberikan kepada guru Fisika ditunjukkan pada Tabel 4. Hasil analisis data diperoleh uji validitas empiris pada aspek desain memiliki rata-rata 4,0, aspek pedagogi 4,0, aspek isi 3,93, dan aspek teknis 4,0 dengan kategori setiap aspek diperoleh hasil yang valid. 
Tabel 3. Hasil uji validitas e-modul oleh peserta didik

\begin{tabular}{|c|c|c|c|}
\hline $\begin{array}{c}\text { Aspek } \\
\text { Penilaian }\end{array}$ & $\begin{array}{c}\text { Item } E \text {-modul } \\
\text { berbasis literasi sains }\end{array}$ & Skor & Kategori \\
\hline \multirow[t]{11}{*}{ Desain } & 1. Desain E-modul radiasi elektromagnetik menarik & 4,74 & VT \\
\hline & 2. Tulisan dalam $E$-modul mudah di baca & 4,30 & VT \\
\hline & 3. Gambar dalam E-modul sesuai isi materi gelombang & & \\
\hline & elektromagnetik & 4,59 & VT \\
\hline & 4. Gambar dalam E-modul membantu pemahaman & 4,57 & VT \\
\hline & 5. Gambar dalam $E$-modul membantu pembelajaran & 4,61 & VT \\
\hline & 6. E-modul radiasi elektromagnetik menggunakan warna yang sesuai & 4,09 & VT \\
\hline & 7. Tombol/tanda yang digunakan dalam $E$-modul mudah dikenal & 4,26 & VT \\
\hline & 8. Kedudukan teks, animasi, dan tanda dalam E-modul konsisten & 4,26 & VT \\
\hline & $\begin{array}{l}\text { 9. Isi } E \text {-modul radiasi elektromagnetik lengkap dengan panduan } \\
\text { penggunaan }\end{array}$ & 4,57 & VT \\
\hline & Skor rerata aspek Desain & 4,44 & VT \\
\hline \multirow[t]{6}{*}{ Pedagogi } & $\begin{array}{l}\text { 1. E-modul membantu peserta didik memahami materi radiasi } \\
\text { elektromagnetik }\end{array}$ & 4,65 & VT \\
\hline & $\begin{array}{l}\text { 2. E-modul mendorong berpikir kreatif dan menumbuhkan semangat } \\
\text { belaiar }\end{array}$ & 4.43 & VT \\
\hline & 3. Penyampaian materi dalam $E$-modul teratur dan mudah diikuti & 4.00 & $\mathrm{~V}$ \\
\hline & $\begin{array}{l}\text { 4. Contoh atau latihan yang diberikan dalam } E \text {-modul sesuai dengan } \\
\text { materi radiasi elektromagnetik }\end{array}$ & 3,91 & V \\
\hline & $\begin{array}{l}\text { 5. Belajar mandiri dengan } E \text {-modul ini dapat menjelaskan materi } \\
\text { radiasi elektromagnetik secara keseluruhan }\end{array}$ & 3,86 & V \\
\hline & Skor rerata aspek Pedagogi & 4,17 & VT \\
\hline \multirow[t]{10}{*}{ Isi } & 1. Bahan pelajaran dalam e-modul disertai latihan soal kuiz & 4,39 & VT \\
\hline & 2. Soal kuiz dalam $e$-modul sesuai dengan materi radiasi & & \\
\hline & 3. Materi pelajaran $E$-modul disertai dengan ujian formatif & $\begin{array}{l}4,50 \\
4,08\end{array}$ & $\begin{array}{l}\text { VI } \\
\text { VT }\end{array}$ \\
\hline & 4. Materi pelajaran $E$-modul disertai dengan ujian sumatif & 4,26 & VT \\
\hline & 5. Ujian formatif dan ujian sumatif sesuai dengan materi radiasi & & \\
\hline & elektromagnetik & 4,65 & VT \\
\hline & 6. Bahan pelajaran dalam e-modul disertai dengan animasi radiasi & & \\
\hline & elektromagnetik & 4,56 & VT \\
\hline & 7. Bahan pelajaran disertai penjelasan materi radiasi elektromagnetik & 4,43 & VT \\
\hline & Skor rerata aspek Isi & 4,42 & VT \\
\hline \multirow[t]{10}{*}{ Teknis } & $\begin{array}{l}\text { 1. Pengguna dapat mengendalikan proses pembelajaran melalui } E \text { - } \\
\text { modul radiasi elektromagnetik }\end{array}$ & 4,26 & VT \\
\hline & 2. E-modul mempunyai banyak cabang kebagian lain & 4,30 & VT \\
\hline & 3. Pengguna tidak terjebak ketika menggunakan $E$-modul & 4,08 & VT \\
\hline & $\begin{array}{l}\text { 4. Langkah-langkah dalam } E \text {-modul radiasi elektromagnetik mudah } \\
\text { diikuti }\end{array}$ & 4,30 & VT \\
\hline & 5. Informasi yang dapat diperoleh dari $E$-modul lebih dari satu & 4,52 & VT \\
\hline & $\begin{array}{l}\text { 6. Melalui E-modul ini pengguna mudah mencari informasi materi } \\
\text { radiasi elektromagnetik }\end{array}$ & 4,39 & VT \\
\hline & 7. Pengguna dapat keluar dari E-modul kapanpun diperlukan & 4,47 & VT \\
\hline & 8. E-modul radiasi elektromagnetik ini mudah digunakan & 4,39 & VT \\
\hline & Skor rerata aspek Teknis & 4,34 & VT \\
\hline & Validitas Media Keseluruhan & 4,34 & VT \\
\hline
\end{tabular}


Aspek isi diperoleh dengan skor terendah, namun masih dalam kategori valid, dan hasil validitas akhir dari e-modul berbasis literasi sains dengan skor 3,99 juga berkategori valid. Terdapat perbedaan kategori hasil penilaian peserta didik (kategori validitas tinggi) dibandingkan hasil penilaian guru (kategori valid), namun keduanya masih dalam kategori valid. Hasil ini berarti bahwa penilaian peserta didik lebih tinggi dibanding penilaian guru, sehingga mereka ternyata senang menggunakan e-modul yang diberikan.

Tabel 4. Hasil uji validitas e-modul oleh guru fisika

\begin{tabular}{|c|c|c|c|}
\hline $\begin{array}{l}\text { Aspek } \\
\text { Penilaian }\end{array}$ & $\begin{array}{c}\text { Item } E \text {-modul } \\
\text { berbasis literasi sains }\end{array}$ & Skor & Kategori \\
\hline \multirow[t]{12}{*}{ Desain } & 1. Desain E-modul radiasi elektromagnetik menarik & 4,0 & $\mathrm{~V}$ \\
\hline & 2. Tulisan dalam $E$-modul mudah dibaca & 3,5 & $\mathrm{~V}$ \\
\hline & 3. Gambar dalam $E$-modul sesuai dengan isi materi & & \\
\hline & gelombang elektromagnetik & 4,5 & VT \\
\hline & $\begin{array}{l}\text { 4. Gambar yang digunakan dalam E-modul membantu } \\
\text { pembelajaran }\end{array}$ & 3,5 & V \\
\hline & 5. E-modul menggunakan warna yang sesuai & 4,0 & $\mathrm{~V}$ \\
\hline & 6. Tombol atau tanda yang digunakan dalam $E$-modul radiasi & & \\
\hline & elektromagnetik mudah dikenal & 4,5 & VT \\
\hline & 7. Kedudukan teks, animasi, dan tanda dalam E-modul adalah & & \\
\hline & konsisten & 3,5 & $\mathrm{~V}$ \\
\hline & 8. Isi E-modul lengkap dengan panduan penggunaan & 4,5 & VT \\
\hline & Skor rerata aspek Desain & 4,0 & $\mathrm{~V}$ \\
\hline \multirow[t]{4}{*}{ Pedagogi } & $\begin{array}{l}\text { 9. Penyampaian materi dalam } E \text {-modul teratur dan mudah } \\
\text { diikuti }\end{array}$ & 3,5 & $\mathrm{~V}$ \\
\hline & 10. Contoh atau latihan soal yang diberikan dalam $E$-modul & & \\
\hline & sesuai dengan materi radiasi elektromagnetik & 4,5 & $\mathrm{~V}$ \\
\hline & Skor rerata aspek Pedagogi & 4,0 & $\mathrm{~V}$ \\
\hline \multirow[t]{12}{*}{ Isi } & 11. Bahan pelajaran dalam $e-m o d u l$ disertai latihan soal kuiz & 4,0 & $\mathrm{~V}$ \\
\hline & 12. Soal kuiz dalam $e-m o d u l$ sesuai dengan materi radiasi & & \\
\hline & elektromagnetik & 4,0 & V \\
\hline & 13. Materi pelajaran didalam $e-m o d u l$ disertai ujian formatif & 3,5 & $\mathrm{~V}$ \\
\hline & 14. Materi pelajaran didalam $E$-modul disertai ujian sumatif & 4,5 & VT \\
\hline & 15. Ujian formatif dan ujian sumatif sesuai dengan materi & & \\
\hline & radiasi elektromagnetik & 3,5 & $\mathrm{~V}$ \\
\hline & 16. Bahan pelajaran dalam $e-m o d u l$ disertai dengan animasi & & \\
\hline & radiasi elektromagnetik & 3,5 & $\mathrm{~V}$ \\
\hline & 17. Bahan pelajaran disertai penjelasan materi radiasi & & \\
\hline & elektromagnetik & 4,5 & VT \\
\hline & Skor rerata aspek Isi & 3,93 & $\mathrm{~V}$ \\
\hline \multirow[t]{12}{*}{ Teknis } & $\begin{array}{l}\text { 18. Pengguna mengendalikan proses pembelajaran dengan } \\
\text { menggunakan } E \text {-modul radiasi elektromagnetik }\end{array}$ & 4,5 & VT \\
\hline & 19. E-modul mempunyai banyak cabang kebagian lain & 4,0 & $\mathrm{~V}$ \\
\hline & $\begin{array}{l}\text { 20. Pengguna tidak terjebak ketika menggunakan } E \text {-modul } \\
\text { materi elektromagnetik }\end{array}$ & 4.0 & $\mathrm{~V}$ \\
\hline & 21. Langkah-langkah dalam $E$-modul mudah diikuti & 3,5 & $\mathrm{~V}$ \\
\hline & 22. Informasi yang diperoleh dari $E$-modul radiasi & & \\
\hline & elektromagnetik lebih dari satu & 4,0 & $\mathrm{~V}$ \\
\hline & 23. Melalui E-modul ini mudah mencari informasi mengenai & & \\
\hline & materi radiasi elektromagnetik & 4,0 & $\mathrm{~V}$ \\
\hline & 24. Pengguna dapat keluar dari E-modul kapanpun & 4,5 & VT \\
\hline & 25.E-modul ini mudah digunakan & 4,0 & $\mathrm{~V}$ \\
\hline & Skor rerata aspek Teknis & 4,0 & $\mathrm{~V}$ \\
\hline & Keseluruhan & 3,99 & V \\
\hline
\end{tabular}


Hasil analisis e-modul berbasis literasi sains pada materi Radiasi Elektromagnetik untuk setiap aspek diuraikan sebagai berikut.

\section{Analisis aspek desain}

Tabel 3 menunjukkan hasil validitas aspek desain dengan nilai berada pada kategori validitas tinggi dan pada Tabel 4 hasil validitas aspek desain dengan skor rata-rata 4 berada pada kategori valid. Hal ini menunjukkan bahwa e-modul berbasis literasi sains sebagai sumber belajar materi radiasi elektromagnetik memiliki kelebihan dalam segi desain yang menarik, yaitu menggunakan warna yang sesuai, tulisan yang mudah dibaca, gambar sesuai dengan isi materi yang dapat membantu pemahaman, memiliki tata letak yang konsisten disertai dengan panduan penggunaan. Hal ini sejalan dengan hasil kajian Helna (2015) dengan hasil 63\% kategori layak dimana komposisi warna sangat berpengaruh terhadap kelayakan e-modul. Artinya komposisi warna berpengaruh kepada ketertarikan peserta didik dalam pembelajaran dan semakin baik komposisi warna dari sebuah e-modul, maka semakin tertarik peserta didik dalam kegiatan pembelajaran melalui e-modul.

\section{Analisis aspek pedagogi}

Tabel 3 diperoleh hasil validitas aspek pedagogi oleh peserta didik dengan nilai skor rata-rata 4,17 berada pada kategori validitas tinggi dan pada Tabel 4 hasil validitas aspek pedagogi oleh Guru Fisika dengan skor ratarata 4 berada pada kategori valid. Hal ini menunjukkan bahwa e-modul berbasis literasi sains sebagai sumber belajar materi radiasi elektromagnetik memiliki kelebihan dalam segi pedagogi, karena e-modul ini dapat membantu pemahaman peserta didik, menumbuhkan semangat belajar, serta penyampaian dalam e-modul ini teratur dan mudah dipahami. Namun demikian, masih terdapat dua item dengan skor rata-rata terendah pada aspek pedagogi yaitu 3,86 dan 3,91 dengan kategori valid. Item dengan skor rata-rata terendah terdapat pada kriteria nomor 14 terkait pernyataan belajar mandiri menggunakan e-modul berbasis literasi sains ini peserta didik dapat menjelaskan materi radiasi elektromagnetik secara keseluruhan dan kriteria No.13 tentang kesesuaian contoh atau latihan soal yang diberikan dalam e-modul berbasis literasi sains dengan materi radiasi elektromagnetik yang disampaikan. Artinya masih terdapat peserta didik yang belum mampu secara optimal memahami latihan yang diberikan, sehingga perlu penekanan pada aspek ini saat diberikan penggunaan e-modul tersebut

Berdasarkan hasil wawancara kepada peserta didik mengenai belajar mandiri menggunakan e-modul, dapat diperoleh bahwa e-modul kurang efektif dalam membantu peserta didik untuk memahami materi radiasi elektromagnetik secara mandiri, sehingga peserta didik tetap memerlukan peranan guru sebagai fasilitator untuk membantu peserta didik dalam memahami pembelajaran fisika. Pembelajaran fisika tidak hanya dapat dijelaskan dengan kalimat saja, diperlukan peranan guru sebagai demonstrator dan mediator untuk menciptakan pembelajaran yang efektif. Hal ini didukung oleh penelitian Yuli (2016) bahwa untuk menciptakan pembelajaran yang efektif diperlukan peranan guru. Guru memiliki peran penting dalam proses pembelajaran yaitu sebagai demonstrator, pembimbing, pengelola kelas, mediator dan juga sebagai evaluator.

\section{Analisis aspek isi}

Tabel 3 menunjukkan hasil skor ratarata aspek isi dengan nilai 4,42 berada pada kategori validitas tinggi dan pada Tabel 4 hasil validitas aspek isi dengan skor rata-rata 3,93 berada pada kategori valid. Hal ini disebabkan karena pada e-modul ini terdapat latihan kuis, ujian formatif dan ujian sumatif yang sesuai dengan materi elektromagnetik, serta kelebihan yang paling menonjol pada aspek isi ini adalah penyajian bahan pelajaran pada $e$ modul ini disertai dengan animasi yang dapat membantu penjelasan mengenai materi yang sulit untuk dipahami oleh peserta didik, sehingga dapat membuat peserta didik lebih mudah dalam memahami materi dan tertarik dalam proses pembelajaran. Hal ini sesuai dengan penelitian Liza (2017) bahwa pembelajaran yang menggunakan animasi sangat membantu peserta didik dalam membangun pengetahuan baru berdasarkan pengetahuan awal yang dimiliki. Pembelajaran menggunakan animasi juga dapat memberikan motivasi belajar peserta didik yang lebih tinggi. 


\section{Analisis aspek teknis}

Tabel 3 diperoleh hasil validitas aspek teknis dengan nilai skor rata-rata 4,34 berada pada kategori validitas tinggi dan pada Tabel 4 hasil validitas aspek teknis dengan skor ratarata 4 berada pada kategori valid. Hal ini disebabkan karena e-modul ini memiliki langkah-langkah yang sederhana dan mudah untuk diikuti. E-modul berbasis literasi sains ini juga mempermudah penggunanya untuk mengetahui informasi yang berkaitan dengan materi radiasi elektromagnetik dan dengan penggunaan e-modul ini juga dapat mengurangi penggunaan kertas yang berlebihan. Kelebihan yang paling menonjol pada aspek teknis ini adalah kemudahan dalam mengoperasikan e-modul yang dihasilkan. Hal ini sesuai dengan penelitian Asmiyunda (2018) dalam komponen kemudahan penggunaan $e$ modul yang memiliki rata-rata kuesioner 4,1 dengan kategori sangat tinggi.

Hasil uji validitas secara aspek desain, aspek pedagogi, aspek isi dan aspek teknis dikatakan valid. Hal ini berarti bahwa sumber belajar tersebut telah diketahui tingkat kebenaran dan ketepatan penggunaan media untuk peserta didik. Analisis empiris e-modul berbasis literasi sains sebagai sumber belajar pada materi radiasi elektromagnetik yang diperoleh adalah valid. Berdasarkan penelitian analisis empiris e-modul berbasis literasi sains yang memperoleh skor rata-rata 4,34 kategori validitas tinggi. Penelitian ini relevan dengan penelitian yang dilakukan oleh Monica Fransisca (2017) didapatkan hasil skor ratarata sumber belajar e-learning sebesar 4,5 dengan kategori sangat valid yang terdiri dari aspek isi, pembelajaran, interaksi dan tampilan. Sumber belajar e-learning ini valid dan dapat digunakan sebagai sumber belajar yang membantu pembelajaran peserta didik. Menurut M. Rahmad et al. (2016) dalam penelitian pengembangan e-modul elektronika dasar berbasis problem based learning mendapatkan hasil validitas dengan rata-rata skor 3,39 berkategori sangat tinggi, sehingga e-modul tersebut dapat digunakan dalam membantu dalam pembelajaran.

\section{Analisis aspek literasi sains}

Terdapat empat kategori untuk menganalisis buku ajar sains yaitu sains sebagai batang tubuh pengetahuan (a body of knowledge), sains sebagai cara untuk menyelidiki (way of investigating), sains sebagai cara berpikir (way of thinking) dan interaksi antara sains, teknologi dan masyarakat (interaction between science, technology and society). Bagian-bagian yang terdapat dalam e-modul berbasis literasi sains yakni:

a. Sains sebagai batang tubuh pengetahuan ( $a$ body of knowledge)

Kategori ini biasanya untuk menampilkan, mendiskusikan atau menanyakan hal-hal untuk mengingat informasi tentang faktafakta, konsep-konsep, prinsip-prinsip, hukum-hukum, teori-teori, dan sebagainya. Kategori ini terdapat pada halaman 12-23 dalam e-modul.

b. Sains sebagai cara untuk menyelidiki (way of investigating)

Kategori ini dimaksudkan untuk menstimulasi berpikir dan melakukan sesuatu dengan menugaskan kepada peserta didik untuk "menyelidiki". E-modul berbasis literasi sains materi radiasi elektromagnetik ini telah dilengkapi dengan kategori ini, hal ini ditunjukkan pada halaman 26-29 dan halaman 40-46 pada $e$ modul.

c. Sains sebagai cara berpikir (way of thinking)

Kategori ini dimaksudkan untuk memberi gambaran sains secara umum dan ilmuwan khususnya dalam melakukan penyelidikan. Hakekat sains mewakili proses berpikir, penalaran (reasoning), dan refleksi dimana peserta didik berbicara tentang berlangsungnya kegiatan ilmiah. E-modul berbasis literasi sains pada materi radiasi elektromagnetik ini telah dilengkapi dengan kategori ini.

d. Interaksi antara sains, teknologi dan masyarakat (Interaction between science, technology, and society)

Kategori ini dimaksudkan untuk memberi gambaran tentang pengaruh atau dampak sains terhadap masyarakat. Peserta didik menerima informasi tersebut dan umumnya tidak harus menemukan atau menyelidiki. E-modul berbasis literasi sains materi radiasi elektromagnetik ini telah dilengkapi dengan kategori ini. 
Penelitian ini relevan dengan penelitian yang dilakukan oleh Wilkinson (1999) yang mendapatkan bahwa e-modul yang bermuatan literasi sains memiliki perbandingan sains sebagai batang tubuh pengetahuan, sains sebagai cara untuk menyelidiki, sains sebagai cara untuk berpikir, dan interaksi antara sains, teknologi, dan masyarakat berturut-turut adalah 1:1:1:2. Keberadaan aspek literasi sains yakni interaksi antara sains, teknologi, dan masyarakat sangat ditekankan dalam penulisan e-modul berbasis literasi sains karena implementasi ilmu sains dalam teknologi dan masyarakat mempengaruhi kemampuan literasi sains peserta didik. Dengan demikian hasil kajian ini telah menghasilkan e-modul berbasis literasi sains yang valid dan laayak digunakan dalam pembelajaran pada materi Radiasi Elektromagnetik yang didukung oleh kajian yang relevan.

Selain keunngulan e-modul yang dihasilkan, masih terdapat kendala terkait suasana kelas yang masih belum optimal, dikarenakan file $e$-modul yang diberikan masih menggunakan flashdisk dan memerlukan waktu yang tidak sedikit, sehingga dalam pembelajaran masih perlu bimbingan intensif dari guru, dan terkait kelebihan penggunanaan waktu pembelajaran.

\section{Kesimpulan dan Saran}

Analisis empiris berdasarkan hasil dan pembahasan uji empiris e-modul berbasis literasi sains pada materi radiasi elektromagnetik dinyatakan valid pada indikator tampilan, pedagogi, isi dan teknis. Emodul radiasi elektromagnetik telah mencapai ketepatan penggunaan dan mencapai tujuan pengembangan sumber belajar tersebut. Dengan demikian, e-modul berbasis literasi sains sebagai sumber belajar pada materi radiasi elektromagnetik dapat digunakan sebagai sumber belajar fisika di SMA/SMK.

Direkomendasikan untuk mengunggah e-modul Radiasi Elektromagnetik berbasis literasi sains ke internet sehingga dapat diakses secara mudah oleh pengguna. Diharapkan guru tetap menggunakan pembelajaran yang dapat membantu peserta didik dalam pembelajaran serta melakukan kajian lanjutan untuk melihat keefektifan atau pengaruh penggunaan $e$ modul berbasis literasi sains sebagai sumber belajar pada materi radiasi elektromagnetik terhadap aspek kognitif ataupun motivasi peserta didik di SMA/MA/SMK.

\section{Daftar Pustaka}

Akaslan \& Taskin, 2011. Analysis of Issues for Implementing E-Learning: The Student Perspective. IEEE, New York.

Andi Prastowo, 2012. Pengembangan Sumber Belajar. Pedagogia, Yogyakarta.

Asmiyunda, Guspatni, \& Fajriah Azra, 2018. Pengembangan E-modul Keseimbangan Kimia Berbasis Pendekatan Saintifik untuk Kelas XI SMA/MA. Universitas Negeri Padang, Padang.

Chiappetta, E.L, D.A. Fillman, \& G.H. Sethna, 1994. Do Middle School Life Science Textbooks Provide a Balance of Scientific Literacy Themes?. Journal of Research in Science Teaching, 30(2): 787-797.

Chiappetta, E.L., D.A. Fillman, \& G.H. Sethna, 1991. A Method to Quantify Major Themes of Scientific Literacy in Science Textbooks. Journal of Research in Science Teaching, 28(8): 713-725.

Dimitros Rigas \& Mohammed Sallam, 2008. An Empiric Study on E-Learning NoteTaking Platform using Multimodal Metaphors. International Journal of Applied Mathematics and Information.

Djaali \& Pudji Muljiono, 2004. Pengukuran dalam Bidang Pendidikan. Program Pascasarjana Universitas Negeri Jakarta, Jakarta.

Gustia Angraini, 2014. Analisi Kemampuan Literasi Sains Siswa SMA Kelas X di Kota Solok. Prossiding Mathematics and Science Forum, 161-170. Universitas Pendidikan Indonesia. Bandung.

Hartono, 2015. Analisis Item Instrumen. Zanafa Publishing, Pekanbaru.

Helna Satriawati, 2015. Pengembangan EModul Interaktif sebagai Sumber Belajar Elektronika Dasar Kelas X SMKN 3 Yogyakarta. Universitas Negeri Yogyakarta.

I Wayan Laba, 2010. Analisis Empiris Penggunaan Insektisida Menuju Pertanian Berkelanjutan. Jurnal 
Pengembangan Inovasi Pertanian, 3(2): 120-137.

Lia Yunita, 2017. Pengaruh Penggunaan Media Animasi terhadap Aktivitas dan Hasil Belajar Siswa pada Materi Sistem Pencernaan di SMP 1 Darussalam. Universitas Islam Negeri Ar-Raniry, Banda Aceh.

Monica Fransisca, 2017. Pengujian Validitas, Praktikalitas, dan Efektivitas Media ELearning di Sekolah Menengah Kejuruan. Universitas Sultan Ageng Tirtayasa.

Munafiah, Azhar \& Muhammad Nasir, 2018. Analisis Empiris Multimedia Interaktif Materi Hukum Newton tentang Gerak sebagai Media Pembelajaran Fisika di SMA Kelas X. Jurnal Online Mahasiswa, Universitas Riau.

Muhammad 'Asyim, Nur Ngazizah, \& Eko Setyadi Kurniawan, 2015. Pengembangan E-Learning Interaktif Fisika Berbasis Literasi Sains Guna Meningkatkan Keterampilan Proses dan Sikap Ilmiah Siswa Kelas X Tahun Pelajaran 2014/2015. Jurnal Radiasi, 7 (2), Universitas Muhammadiyah Purworejo, Purworejo.

Muhammad Nasir, 2014. Pembangunan dan Penilaian Keberkesanan Perisian Pengajaran dan Pembelajaran Fizik Berbantukan Komputer di Sekolah Menengah Atas Pekanbaru, Riau Indonesia. Disertasi tidak dipublikasikan. Universiti Kebangsaan Malaysia. Malaysia.

M. Rahmad, Norazah Mohd Nodin, \& Ernidawati. 2016. Pengembangan Modul Elektronika Dasar Berbasis
Problem Based Learning. Universitas Riau, Pekanbaru. Proseding Seminar Nasional UPP. Universitas Pasir Pengaraian.

Nana Nurjannati, M. Rahmad, \& Mitri Irianti. 2017. Pengembangan E-Modul Berbasis Literasi Sains Pada Materi Radiasi Elektromagnetik. Jurnal Online Mahasiswa.Universitas Riau.

Nelda Azhar \& Muhammad Adri, 2008. Uji Validitas dan Reliabilitas E-media Fisika Terapan di Jurusan Teknik Elektronika. Universitas Negeri Padang.

Siti Maghfirotun \& Heri Kiswanto, 2011. Pengembangan Media Pembelajaran Interaktif Berbantuan Komputer pada Materi Dimensi Tiga. Jurnal Jurusan Matematika FMIPA Universitas Negeri Surabaya.

Wai Kit Wong \& Poh Kiat Ng. 2016. An Empirical Study on E-Learning versus Traditional Learning among Electronics Engineering Student. American Journal of Applied Sciences.

Wilkinson, J., 1999. A Quantitative Analysis of Physics Textbooks for Scientific Literacy. Research in Science Education, 29(3): 385-399.

Yuli Alvianti. 2012. Efektivitas Media Pocket Book dalam Pembelajaran Fisika Pokok Bahasan Gelombang Elektromagnetik untuk Meningkatkan Hasil Belajar Fisika Siswa Kelas X MAN Rembang. Universitas Islam Negeri Sunan Kalijaga, Yogyakarta.

Yuni Kusuma Astuti. 2016. Literasi Sains dalam Pembelajaran IPA. Journal Pendidikan Fisika, 3(7): 67-72. 